\title{
Geology
}

\section{Metamorphic rates in collisional orogeny from in situ allanite and monazite dating}

Emilie Janots, Martin Engi, Daniela Rubatto, Alfons Berger, Courtney Gregory and Meinert Rahn

Geology 2009;37;11-14

doi:10.1130/G25192A.1

\section{E-mail alerting services}

\section{Subscribe}

Permission request click www.gsapubs.org/cgi/alerts to receive free e-mail alerts when new articles cite this article

click www.gsapubs.org/subscriptions/index.ac.dtl to subscribe to Geology

click http://www.geosociety.org/pubs/copyrt.htm\#gsa to contact GSA

Copyright not claimed on content prepared wholly by U.S. government employees within scope of their employment. Individual scientists are hereby granted permission, without fees or further requests to GSA, to use a single figure, a single table, and/or a brief paragraph of text in subsequent works and to make unlimited copies of items in GSA's journals for noncommercial use in classrooms to further education and science. This file may not be posted to any Web site, but authors may post the abstracts only of their articles on their own or their organization's Web site providing the posting includes a reference to the article's full citation. GSA provides this and other forums for the presentation of diverse opinions and positions by scientists worldwide, regardless of their race, citizenship, gender, religion, or political viewpoint. Opinions presented in this publication do not reflect official positions of the Society.

\section{Notes}




\title{
Metamorphic rates in collisional orogeny from in situ allanite and
}

\section{monazite dating}

\author{
Emilie Janots ${ }^{1 *}$, Martin Engi ${ }^{1}$, Daniela Rubatto ${ }^{2}$, Alfons Berger ${ }^{1}$, Courtney Gregory ${ }^{2}$, Meinert Rahn ${ }^{3}$ \\ 'Institut für Geologie, Universität Bern, Blatzerstrasse 3, CH-3012 Bern, Switzerland \\ ${ }^{2}$ Research School of Earth Sciences, The Australian National University, Canberra ACT 0200, Australia \\ ${ }^{3}$ Hauptabteilung für die Sicherheit der Kernanlagen (HSK), CH-5232 Villingen, Switzerland
}

\section{ABSTRACT}

The prograde sequence of rare earth minerals recorded in metapelites during regional metamorphism reveals a series of irreversible reactions among silicates and phosphates. In individual samples from the northern Lepontine (Central Alps), allanite is partly replaced by monazite at 560-580 ${ }^{\circ} \mathrm{C}$. Relic allanite retains its characteristic growth zoning acquired at greenschist facies conditions $\left(430-450{ }^{\circ} \mathrm{C}\right)$. Coexisting monazite and allanite were dated in situ to delimit in time successive stages of the Barrovian metamorphism. In situ sensitive high-resolution ion microprobe (SHRIMP) U-Th-Pb dating of allanite (31.5 \pm 1.3 and $29.2 \pm 1.0 \mathrm{Ma})$ and monazite $(18.0 \pm 0.3$ and 19.1 $\pm 0.3 \mathrm{Ma})$ constrains the time elapsed between 430-450 ${ }^{\circ} \mathrm{C}$ and $560-580{ }^{\circ} \mathrm{C}$, which implies an average heating rate of 8-15 ${ }^{\circ} \mathrm{C} / \mathrm{m} . y$. Combined with new fission track ages (zircon, 10-9 Ma; apatite, 7.5-6.5 Ma), metamorphic rates of the entire orogenic cycle, from prograde to final cooling, can be reconstructed.

\section{INTRODUCTION}

The evolution of the thermal structure during continental collision is difficult to discern from field studies alone, and numerical models are commonly used to display the transient thermal field (e.g., Bousquet et al., 1998; Roselle et al., 2002). Key uncertainties in these models include the tectonometamorphic rates, which are often controversial owing to discrepancies among geochronological studies, even in classic metamorphic belts such as the Alps (e.g., Gebauer, 1999; Hunziker et al., 1992). Only by correlating high-resolution ages with precisely determined metamorphic conditions is it possible to derive a correct chronological sequence and to obtain rates of processes, and hence robust tectonic implications (Rubatto and Hermann, 2001; Vance et al., 2003). Early metamorphic stages in particular are difficult to quantify, simply because few chronometers preserve isotopic signatures of prograde metamorphism, without adjustment upon further heating. Attempts to derive heating rates have combined age dating and thermobarometry of garnet (e.g., Vance and O'Nions, 1992). Promising results also came from in situ dating of distinct domains in U-Thbearing minerals such as monazite, the light rare earth element phosphate $\left(\mathrm{LREEPO}_{4}\right)$ and zircon $\left(\mathrm{ZrSiO}_{4}\right)$ (e.g., Foster et al., 2004; Hermann and Rubatto, 2003), yet prograde ages remain rare in collisional orogens and in subduction environments, especially at low temperatures, where chemical and isotopic equilibration may be restricted to micrometer domains.

The determination of heating rates requires microdating of grains (or crystal zones) that record distinct metamorphic stages and show local equilibration at known temperature and

*Current address: Institut für Mineralogie, WWU Münster, Corrensstrasse 24, 48149 Münster, Germany pressure. The recent success in dating allanite in situ (Gregory et al., 2007) offers new possibilities in this respect. Allanite $(\mathrm{Ca}, \mathrm{REE}, \mathrm{Y})_{2}(\mathrm{Al}, \mathrm{Fe})_{3}$ $\left(\mathrm{SiO}_{4}\right)_{3} \mathrm{OH}$ is one of the main hosts of REEs in the crust; it occurs from greenschist to eclogite facies and in magmatic conditions (Hermann, 2002; Janots et al., 2007; Wing et al., 2003).

In this study we present ages of texturally related allanite and monazite in samples from the Lepontine, a part of the Central Alps, where early geochronometry was developed (e.g., $\mathrm{Rb}$-Sr; Jäger, 1962). The Lepontine is excellent for this study, as it records a well-characterized progressive metamorphic sequence. Samples were chosen based on a detailed petrographic inventory of prograde REE assemblages in metapelites (Janots et al., 2008). The ages and metamorphic rates obtained, and fission track dates of zircon and apatite, are discussed in terms of their thermal implications.

\section{GEOLOGICAL SETTING}

The evolution of the Swiss Central Alps involved early subduction followed by a collisional stage. Rapid exhumation was triggered by the combined effects of extension, backthrusting, and efficient erosion (Pfiffner et al., 2000; Schmid et al., 1996). In the Lepontine area, imbricated thrust sheets mainly comprise pre-Alpine basement units formed chiefly during the Caledonian (470-445 Ma) and Variscan (360-260 Ma) orogenies (Berger et al., 2005). Younger (meta)sediments recording only the Alpine orogeny were used for our study, and these notably occur in the external parts of the belt. Slivers of a tectonic mélange unit, which include high-pressure relics, are intercalated within the nappe stack. Most of the high-pressure (HP) fragments dated are Eocene in age (3343 Ma; Brouwer et al., 2005; Gebauer, 1999; Hermann et al., 2006). It is important to realize that the main part of the crystalline thrust sheets in the Lepontine show no evidence of an early HP history, but only the medium-pressure metamorphism that overprinted the entire domain. Mineral zones and metamorphic isograds outline a classic Barrovian belt with isotherms forming a concentric pattern (Fig. 1; Todd and Engi, 1997). This pattern cuts the polydeformed nappe boundaries, hence the thermal peak was reached postkinematically. Greenschist to middle amphibolite facies prevail in the northern parts of the Lepontine, sillimanite grade is reached in the south, and an Alpine migmatite belt formed near the Insubric Line, which truncates the belt in the south. In the southern part of the belt, Barrovian heating was inferred to have peaked between 32.4 Ma and $27 \mathrm{Ma}$ (Gebauer, 1999; Vance and O'Nions, 1992). Several robust geochronometers suggest that the metamorphic peak and subsequent exhumation were reached earlier in the internal (southern) parts (Engi et al., 1995; Hurford, 1986) than in the north, but the interpretation of the numerous metamorphic ages from lower grade (i.e., northern) parts of the belt remains problematic. Pertinent constraints derive from the stratigraphic age of the youngest flysch involved, and require sedimentation to have proceeded up to the Ypresian; i.e., burial of the European margin started after ca. $50 \mathrm{Ma}$ (Steinmann, 1994). Typical Ar-Ar and Rb-Sr isotopic data in the northern Lepontine range from 42 to 16 Ma (Hunziker et al., 1992), spanning most of the Alpine collision-exhumation cycle. In the north of the Lepontine dome (at $2000 \mathrm{~m}$ altitude), fission track cooling ages of zircon are between 14 and 12.2 Ma, while apatite ages are mainly 9-5 Ma (Hurford, 1986; Michalski and Soom, 1990). The uncertainties in the metamorphic ages translate to large uncertainties in heating and cooling rates. For example, Hurford (1986) combined $\mathrm{Rb}-\mathrm{Sr}$ data on muscovite with zircon fission track data to derive a cooling rate of $50-80^{\circ} \mathrm{C} / \mathrm{m}$.y. for the southern Lepontine in the period from 23 to $16-12 \mathrm{Ma}$.

\section{SEQUENCE OF REE-MINERALS}

The progressive sequence of REE minerals in post-Variscan metasediments in the Central Alps has been investigated (Janots et al., 2008) and is summarized here. Samples studied along a north-south profile record conditions from very low grade metamorphism to amphibolite facies grade. Up to subgreenschist facies 


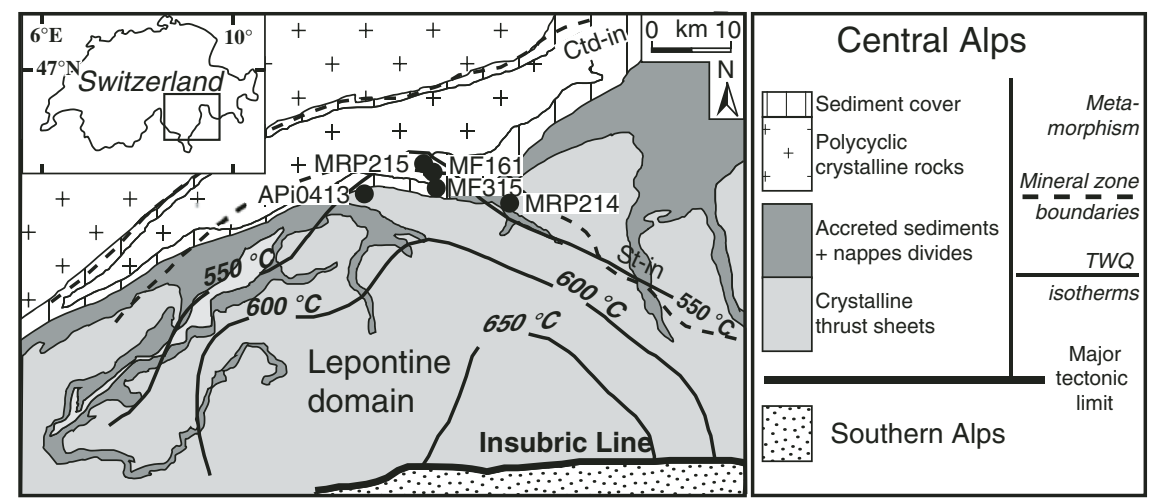

Figure 1. Tectonic sketch map of Central Alps showing sample locations, mineral zone boundaries, and isotherms (Engi et al., 1995). Ctd-chloritoid; St-staurolite; TWQ-thermobarometry with estimation of equilibration state.

conditions, monazite was found as inherited grains, with mainly Variscan chemical ages, and as tiny Alpine grains. Upon appearance of chloritoid, monazite breaks down, and allanite $\left(\sum\right.$ LREE $_{2} \mathrm{O}_{3} \sim 22 \mathrm{wt} \% ; \mathrm{Y}_{2} \mathrm{O}_{3}+\Sigma \mathrm{HREE}_{2} \mathrm{O}_{3}$ $<1 \mathrm{wt} \%$; $\mathrm{UO}_{2}<0.05 \mathrm{wt} \%$ ) is found oriented in the main foliation of the matrix or as inclusions in porphyroblasts of chloritoid. Monazite appears to have reacted with chlorite to form allanite, xenotime, apatite, and chloritoid. This reaction was estimated to occur at $430-450{ }^{\circ} \mathrm{C}$ based on the thermometer of Beyssac et al. (2002), using Raman spectroscopy on carbonaceous material. This estimate is consistent with other temperatures reported in this region (Livi et al., 2002). Prior to garnet growth, allanite acquired one or two successive rims. The rims are rich in clinozoisite component, with the first rim (Cz1) enriched in Y, HREE, and $\mathrm{U}\left(\sum \mathrm{LREE}_{2} \mathrm{O}_{3}\right.$ $<2.5 \mathrm{wt} \% ; \sum \mathrm{Y}_{2} \mathrm{O}_{3}+\mathrm{HREE}_{2} \mathrm{O}_{3} \sim 3.5 \mathrm{wt} \%$; $\mathrm{UO}_{2}$ $\sim 0.2-0.42 \mathrm{wt} \%)$, and the outer rim (Cz2) having very minor REE contents $\left(\mathrm{SY}_{2} \mathrm{O}_{3}+\mathrm{REE}_{2} \mathrm{O}_{3}\right.$ $\sim 0.25 \mathrm{wt} \%$ ). Following garnet growth, above $\sim 560-580{ }^{\circ} \mathrm{C}$, allanite is partially or totally replaced by monazite associated with plagioclase ( \pm biotite \pm staurolite) in samples bearing garnet-kyanite-biotite-staurolite assemblages.

\section{SAMPLES AND AGES}

Three samples from the allanite-monazite transition zone (Fig. 1) were dated in situ in thin sections: allanite in sample MF161, monazite in MF315, and both minerals coexisting in APi0413. None of these samples derive from units with a prior high-pressure history. Zircon and apatite fission track ages were obtained in two samples from crystalline basement units (MRP214 and MRP215; Fig. 1) that were exhumed jointly with the metasediments dated.

Sample MF161, a homogeneous Ca-poor metapelite $(\mathrm{CaO}=0.3 \%)$ containing a quartzmuscovite-chloritoid-kyanite-staurolite association stems from close to the kyaniteand staurolite-zone boundaries. A maximum temperature of $530 \pm 20{ }^{\circ} \mathrm{C}$ was determined using the thermometer of Beyssac et al. (2002).
Allanite occurs as agglomerated grains surrounded by the $\mathrm{Cz} 1 \mathrm{rim}$ (Fig. 2A). Allanite did not undergo partial replacement by monazite. A $\mathrm{Th}-\mathrm{Pb}$ age of $29.2 \pm 1.1 \mathrm{Ma}$ was obtained for allanite analyzed by sensitive high-resolution ion microprobe (SHRIMP) (Fig. 3A). The Cz1 rim could not be dated because of high proportions of common $\mathrm{Pb}$.

Sample APi0413 is a heterogeneous metapelite containing the assemblage garnet-plagioclasebiotite-staurolite-ky anite-muscovite; equilibrium conditions of $560 \pm 30{ }^{\circ} \mathrm{C}$ and $0.85 \pm 0.05 \mathrm{GPa}$ were derived using TWQ (thermobarometry with estimation of equilibration state; Berman, 1988). Allanite always occurs (with its two rims, $\mathrm{Cz} 1$ and $\mathrm{Cz} 2$; Fig. 2B) in the main foliation or as inclusions in garnet. Hence, allanite formed on the prograde path, prior to the growth of garnet porphyroblasts during a phase of post-nappe folding (e.g., Berger et al., 2005). Depending on the $\mathrm{CaO} / \mathrm{NaO}$ content of the rock, allanite shows replacement by monazite following the reaction (details in Janots et al., 2008): allanite + apatite $+\mathrm{Al}-\mathrm{Fe}-\mathrm{Mg}$ phases $1 \Rightarrow$ monazite + anorthite $+\mathrm{Al}-\mathrm{Fe}-\mathrm{Mg}$ phases 2 .

In layers with high $\mathrm{CaO} / \mathrm{NaO}$ ratios, allanite is the only REE mineral; in domains with low $\mathrm{CaO} / \mathrm{NaO}$ the above reaction proceeded: the allanite core was partially or totally replaced by
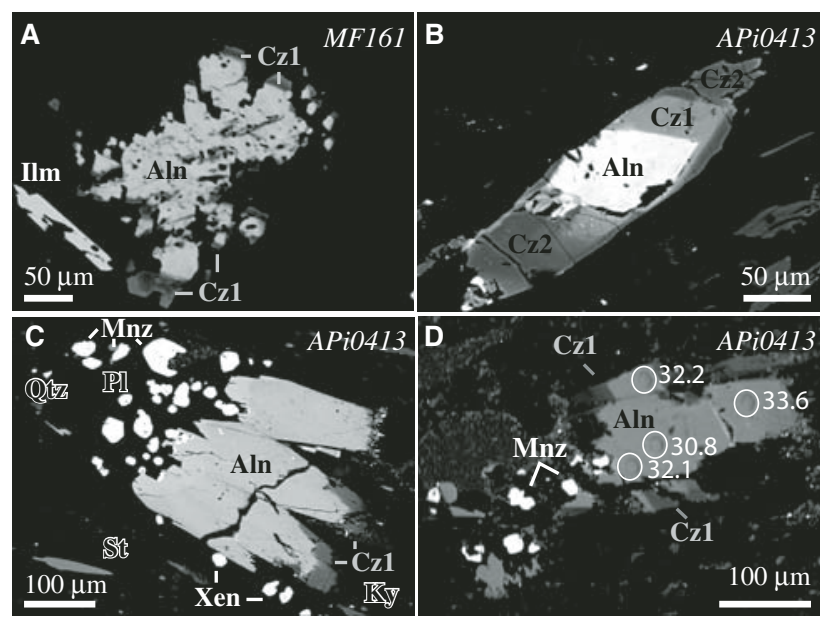

monazite (Fig. 2C), the HREE-rich rim (Cz1) was partially or totally replaced by xenotime; both phosphates are associated with plagioclase and biotite ( \pm staurolite). The preservation of the geometrically distinctive REE zoning demonstrates the immobility and in situ redistribution of the LREE and HREE in phosphate phases upon breakdown of the epidote minerals. While allanite was invariably preserved as inclusions throughout garnet prophyroblasts, monazite is found only in the matrix. In sample APi0413, Th-Pb measurements on allanite by SHRIMP yield an age of $31.5 \pm$ 1.3 Ma (Figs. 2D and 3B). U-Pb SHRIMP analyses of U-rich clinozoisite yield a Tera-Wasserburg intercept age of $18.9 \pm 1.1 \mathrm{Ma}$ (Fig. 3D). Similarly, $\mathrm{U}-\mathrm{Pb}$ analyses of monazite from the same sample define an intercept age of $18.0 \pm 0.3 \mathrm{Ma}$ (Fig. 3C). Three monazite analyses are slightly younger and were excluded from the calculation (age with all data points $17.8 \pm 0.3 \mathrm{Ma}$ ).

Sample MF315, a homogeneous metapelite $(\mathrm{CaO}=0.3 \%)$ rich in staurolite, with sparse garnet, biotite, and kyanite, yields TWQ equilibrium conditions of $580 \pm 30{ }^{\circ} \mathrm{C}$ and $0.9 \pm 0.1 \mathrm{GPa}$. The REE mineralogy is comparable to sample APi0413, except that allanite has but one clinozoisite rim (HREE-rich Cz1). Monazite and allanite are commonly found together, associated with staurolite and quartz. In sample MF315 allanite dating was inconclusive due to high common $\mathrm{Pb}$ contents. Monazite analyzed by SHRIMP yielded a U-Pb age of $19.1 \pm 0.3 \mathrm{Ma}$ (Fig. 3E), with the exclusion of two analyses on a grain presenting unusual zoning as well as $\mathrm{Th} / \mathrm{U}$ composition, and an apparent older age (age including all analyses $19.4 \pm 0.5 \mathrm{Ma})$.

MRP214 and MRP215 are two samples from pre-Variscan crystalline basements. MRP214 is a biotite-bearing orthogneiss and MRP215 is a schistose granite with large K-feldspar blasts. Both samples are overprinted by Alpine metamorphism, with respect to the regional organization of the isotherms (Fig. 1). MRP215 underwent greenschist facies conditions, whereas MRP214 records slightly higher conditions (greenschist-amphibolite facies boundary).
Figure 2. Backscattered scanning electron microscope images. A: Allanite grain with clinozoisite (Cz1) rim in MF161. B: Allanite with two clinozoisite rims $\mathrm{Cz1}$ and $\mathrm{Cz2}$ in $\mathrm{APi0413}$ C: In situ breakdown of allanite and $\mathrm{Cz} 1$ to monazite and xenotime (Xen) associated with staurolite (St), kyanite (Ky), and plagioclase (PI) in APi0413. D: Allanite replacement by monazite with measured $\mathrm{Th}-\mathrm{Pb}$ ages $(\mathrm{Ma})$ beside the SHRIMP (sensitive highresolution ion microprobe) pits in APi0413. 
In samples MRP214 and MRP215, zircon and apatite fission track ages yield consistent age ranges of 9-10 Ma and 6.5-7.5 Ma, respectively.

\section{DISCUSSION}

\section{Age Interpretation}

Compared with geochronology based on single minerals such as zircon, the combined dating of monazite and allanite has the advantage that these phases reflect reactions involving major metamorphic minerals (e.g., chloritoid and plagioclase), which can be correlated with specific pressure-temperature conditions. The progressive sequence of REE minerals in the Central Alps shows that allanite formed from monazite above the chloritoid-in mineral boundary, at $430-450{ }^{\circ} \mathrm{C}$. This estimate is consistent with the first appearance of allanite at $400-450{ }^{\circ} \mathrm{C}$ documented elsewhere (Janots et al., 2006; Wing et al., 2003). The presence in the newly formed allanite of initial radiogenic $\mathrm{Pb}$ inherited from the monazite is ruled out by the free regression of uncorrected isotopic ratios (see Methods in the GSA Data Repository ${ }^{1}$ ), which points to a model common $\mathrm{Pb}$ composition. The preservation of the characteristic textural and chemical zoning of allanite indicates that it did not undergo reequilibration following its prograde formation under greenschist facies. This is confirmed by allanite ages that are comparable in samples with conditions below (MF161, 29.2 $\pm 1.0 \mathrm{Ma}$ ) and above (APi0413, $31.5 \pm 1.3 \mathrm{Ma})$ the appearance of monazite. However, U-rich clinozoisite dated in sample APi0413 gave the same age as monazite, yet the $\mathrm{Th} / \mathrm{U}$ ratio corresponds to the $\mathrm{Cz} 1 \mathrm{rim}$. The petrological significance of this age is not quite clear, but this U-rich clinozoisite appears to have formed when allanite broke down to form monazite (ca. 19-18 Ma). The textural association of monazite with the highest grade metamorphic phases and the absence of monazite in samples below $560{ }^{\circ} \mathrm{C}$ (e.g., in MF161) indicate that the monazite ages reflect conditions very near the thermal peak of metamorphism. Monazite ages of 19-18 Ma continue the spatial younging trend from south to north (U-Pb ages in Engi et al., 1995). They render doubtful earlier interpretations of $\mathrm{Rb}-\mathrm{Sr}$ ages of phengite, from which the metamorphic peak in the northern Lepontine was set at 38-35 Ma (e.g., Hunziker et al., 1992).

\section{Rates of Metamorphism}

In this study, it was possible to date two distinct successive stages of the Barrovian metamorphism in situ and even within the same sample display-

${ }^{1}$ GSA Data Repository item 2009004, methods and Tables DR1 (allanite U-Th-Pb data), DR2 (clinozoisite U-Th- $\mathrm{Pb}$ data), DR3 (monazite U-Th- $\mathrm{Pb}$ data, in APi0413), DR4 (monazite U-Th-Pb data, in MF315), DR5 (fission track data), and DR6 (sample coordinates), is available online at www.geosociety. org/pubs/ft2009.htm, or on request from editing@ geosociety.org or Documents Secretary, GSA, P.O. Box 9140, Boulder, CO 80301, USA.
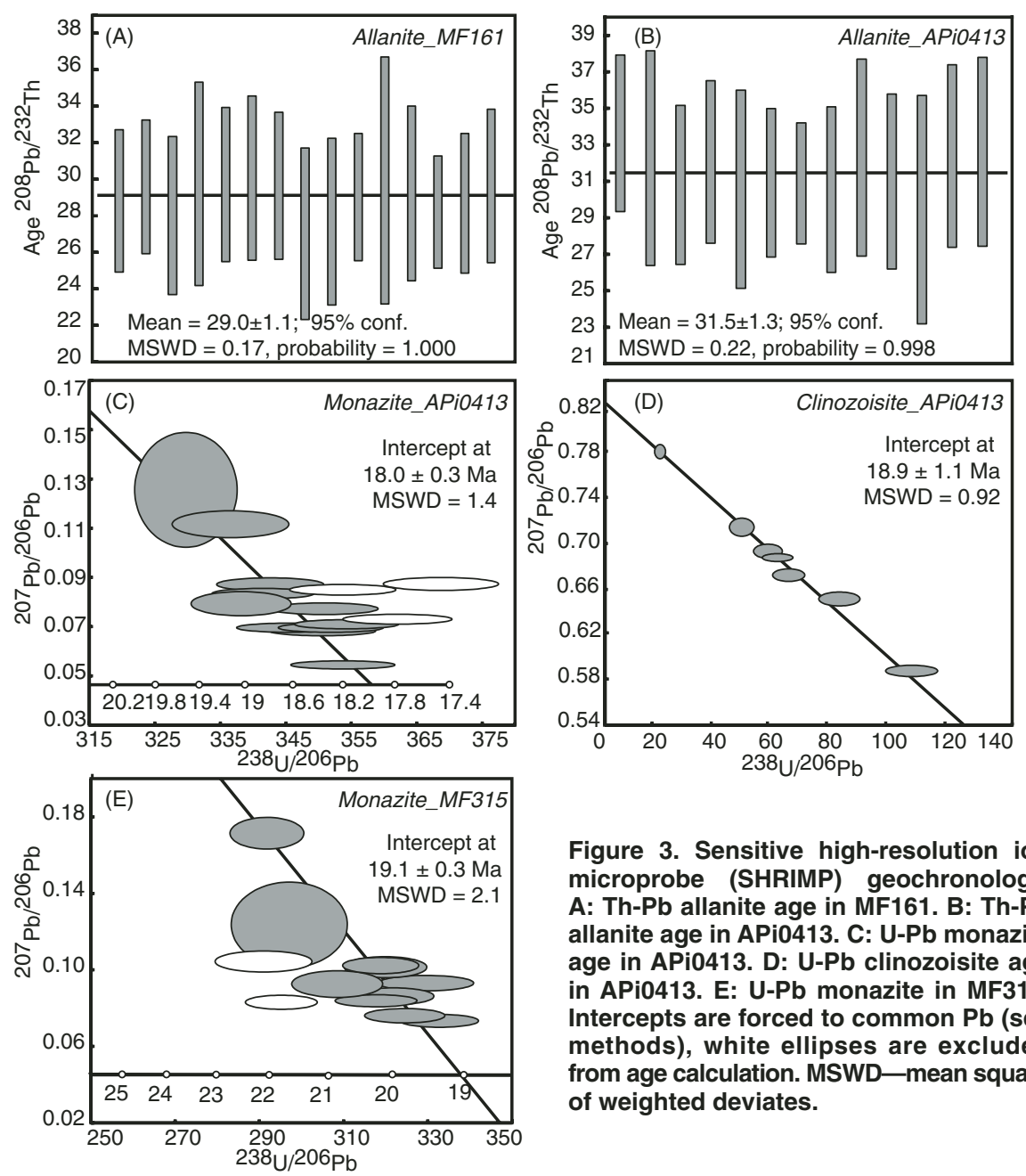

Figure 3. Sensitive high-resolution ion microprobe (SHRIMP) geochronology. $\mathrm{A}$ : Th-Pb allanite age in MF161. B: Th-Pb allanite age in APi0413. C: U-Pb monazite age in APi0413. $\mathrm{D}$ : U-Pb clinozoisite age in APi0413. E: U-Pb monazite in MF315. Intercepts are forced to common $\mathrm{Pb}$ (see methods), white ellipses are excluded from age calculation. MSWD-mean square of weighted deviates.

ing partial breakdown of allanite to monazite. Allanite (31.5-29.2 Ma) and monazite (19.1$18.0 \mathrm{Ma})$ ages constrain the time elapsed between $430{ }^{\circ} \mathrm{C}$ and $450{ }^{\circ} \mathrm{C}$ and $560-580{ }^{\circ} \mathrm{C}$ to 10 13.5 m.y., which implies an average heating rate of $8-15^{\circ} \mathrm{C} / \mathrm{m}$.y. This value is comparable but more precise than the rate of $12.8^{\circ}(+13.6 /-4.4) /$ m.y. derived by Vance and O'Nions (1992) for the Simplon area, located $\sim 50 \mathrm{~km}$ farther west, in a tectonic position similar to that of the Central Alps. Assuming closure temperatures of 250 and $120^{\circ} \mathrm{C}$ for fission track in zircon and apatite (e.g., Brandon et al. 1998), cooling rates of 30$40{ }^{\circ} \mathrm{C} / \mathrm{m}$.y. are derived between 560 and $250{ }^{\circ} \mathrm{C}$, and $35-85^{\circ} \mathrm{C} / \mathrm{m}$.y. between 250 and $120^{\circ} \mathrm{C}$.

Combining these results with data from the literature and the new fission track ages, the entire temperature-time path from accretion to exhumation is now well constrained (Fig. 4) for external parts of the Alpine orogen. The onset of accretion is not precisely delimited, but the regionally youngest flysch strata are of Ypresian age (ca. $50 \mathrm{Ma}$ ). The initial stage prior to the appearance of allanite must have lasted at most 20 m.y. During early heating, allanite formed within the main composite foliation (S2-S3), which is thought to reflect nappe stacking. Porphyroblasts of minerals characteristic of the Barrovian meta-

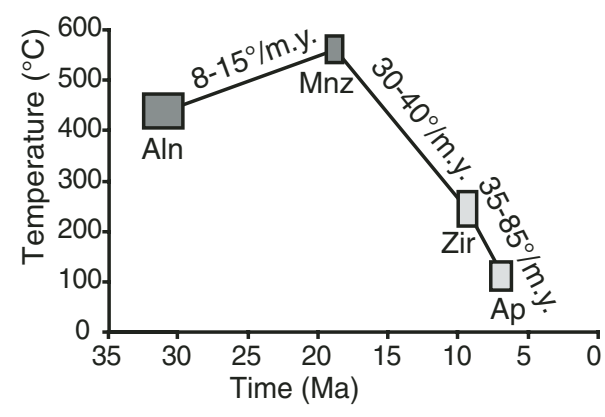

Figure 4. Temperature-time diagram from accretion to exhumation of northern parts of Central Alps. Bold lines correspond to metamorphic rates derived from ages determined in this study (dark gray: U-Th-Pb dating, light gray: fission track dating).

morphism overgrew that foliation between 29.231.5 Ma and 18.0-19.1 Ma, with an average heating rate of $15-8{ }^{\circ} \mathrm{C} / \mathrm{m}$.y. Average cooling rates of $35-45^{\circ} \mathrm{C} / \mathrm{m}$.y. between 560 and $120{ }^{\circ} \mathrm{C}$ characterize the exhumation, which involved short-lived tectonic unroofing and erosion $(0.4-0.5 \mathrm{~km} / \mathrm{m}$.y.; Schlunegger and Willett, 1999).

\section{Diachronicity Across the Orogen}

The Central Alps reflect a pronounced diachronicity in the thermal evolution of the main 
Barrovian phase: $T_{\max }$ in the south was reached at 30-28 Ma, in the central Lepontine at 24-22 Ma (based on $\mathrm{U}-\mathrm{Pb}$ of monazite and zircon from the internal margin, as discussed in Engi et al., 1995), and in the north at 19.1-18.0 Ma (external margin; this work). Similarly, cooling reached zircon and apatite fission track closure at 18-14 and 13-6 Ma in the south, and at 10-9 and 7.56.5 Ma in the north (Hurford 1986; Michalski and Soom, 1990). In the Lepontine, only a few of the tectonically higher units contain highpressure fragments that testify to a complex preBarrovian history. The youngest eclogites dated from these mélange units were formed as late as 33-36 Ma (Lu/Hf in garnet, Brouwer et al., 2005; U-Pb in zircon, Hermann et al., 2006) at pressures of $2.1 \mathrm{GPa}$. The eclogite relics underwent rapid extrusion from mantle depth and were finally incorporated in the Alpine nappe stack. Assembly of these tectonic slivers (with a HP history) and a frontal accretionary prism wedged these fragments in between massive gneiss nappes, in which no evidence of HP has been found. The Barrovian temperature-time path determined here reflects thermal relaxation following this complex tectonic scenario, in the frontal accretionary wedge (in units with no early HP). Given the major differences in dynamics within a metamorphic belt, it appears pointless to expect uniform ages and metamorphic rates across orogens, except to note that heating rates documented in recent years vary by less than an order of magnitude (Foster et al., 2004).

\section{ACKNOWLEDGMENTS}

This research project was financially supported by the Swiss National Science Foundation (grants 20020-101826/1 and 200021-103479) and the Australian Research Council (grant DP0556700). The paper was greatly improved by constructive comments from S. Duchene, L. Jolivet, and R. Parrish.

\section{REFERENCES CITED}

Berger, A., Mercolli, I., and Engi, M., 2005, The Central Lepontine Alps: Notes accompanying the tectonic and petrographic map sheet Sopra Ceneri (1:100,000): Schweizerische Mineralogische und Petrographische Mitteilungen, v. 85 , p. $109-146$.

Berman, R.G., 1988, Internally-consistent thermodynamic data for minerals in the system $\mathrm{Na}_{2} \mathrm{O}-\mathrm{K}_{2} \mathrm{O}-\mathrm{CaO}-\mathrm{MgO}-\mathrm{FeO}-\mathrm{Fe}_{2} \mathrm{O}_{3}-\mathrm{Al}_{2} \mathrm{O}_{3}-$ $\mathrm{SiO}_{2}-\mathrm{TiO}_{2}-\mathrm{H}_{2} \mathrm{O}-\mathrm{CO}_{2}$ : Journal of Petrology, v. 29 , p. $445-522$.

Beyssac, O., Goffé, B., Chopin, C., and Rouzaud, J.N., 2002, Raman spectra of carbonaceous material in metasediments: A new geothermometer: Journal of Metamorphic Geology, v. 20, p. 859-871, doi: 10.1046/j.1525-1314.2002.00408.x.

Bousquet, R., Öberhansli, R., Goffé, B., Jolivet, L., and Vidal, O., 1998, High-pressure-lowtemperature metamorphism and deformation in the Bundnerschiefer of the Engadine window: Implications for the regional evolution of the eastern Central Alps: Journal of Metamorphic Geology, v. 16, p. 657-674, doi: 10.1111/j.1525-1314.1998.00161.x.

Brandon, M.T., Roden-Tice, M.K., and Garver, J.I., 1998, Late Cenozoic exhumation of the
Cascadia accretionary wedge in the Olympic Mountains, northwest Washington State: Geological Society of America Bulletin, v. 110, p. 985-1009, doi: 10.1130/0016-7606 (1998) $110<0985$ :LCEOTC $>2.3 . C O ; 2$.

Brouwer, F.M., Burri, T., Engi, M., and Berger, A., 2005, Eclogite relics in the Central Alps: PT-evolution, Lu-Hf ages and implications for formation of tectonic mélange zones: Schweizerische Mineralogische und Petrographische Mitteilungen, v. 85, p. 147-174.

Engi, M., Todd, C.S., and Schmatz, D.R., 1995, Tertiary metamorphic conditions in the eastern Lepontine Alps: Schweizerische Mineralogische und Petrographische Mitteilungen, v. 75, p. 347-369.

Foster, G., Parrish, R.R., Horstwood, M.S.A., Chenery, S., Pyle, J., and Gibson, H.D., 2004, The generation of prograde P-T-t points and paths; a textural, compositional, and chronological study of metamorphic monazite: Earth and Planetary Science Letters, v. 228, p. 125142, doi: 10.1016/j.eps1.2004.09.024.

Gebauer, D., 1999, Alpine geochronology of the Central and Western Alps: New constraints for a complex geodynamic evolution: Schweizerische Mineralogische und Petrographische Mitteilungen, v. 79, p. 191-208.

Gregory, C.J., Rubatto, D., Allen, C., Williams, I.S., Hermann, J., and Ireland, T.R., 2007, Allanite micro-geochronology: A SHRIMP and LA-ICP-MS study: Chemical Geology, v. 245 , p. 162-182, doi: 10.1016/j.chemgeo. 2007.07.029.

Hermann, J., 2002, Allanite: Thorium and light rare earth element carrier in subducted crust: Chemical Geology, v. 192, p. 289-306, doi: 10.1016/ S0009-2541(02)00222-X.

Hermann, J., and Rubatto, D., 2003, Relating zircon and monazite domains to garnet growth zones: Age and duration of granulite facies metamorphism in the Val Malenco lower crust: Journal of Metamorphic Geology, v. 21, p. 833-852.

Hermann, J., Rubatto, D., and Trommsdorff, V., 2006, Sub-solidus Oligocene zircon formation in garnet peridotite during fast decompression and fluid infiltration (Duria, Central Alps): Mineralogy and Petrology, v. 88, p. 181-206, doi: 10.1007/s00710-006-0155-3.

Hunziker, J.C., Desmons, J., and Hurford, A.J., 1992, Thirty-two years of geochronological work in the Central and Western Alps: A review on seven maps: Mémoires de Géologie (Lausanne), no. 13,59 p.

Hurford, A.J., 1986, Cooling and uplift patterns in the Lepontine Alps, south-central Switzerland and an age of vertical movement on the Insubric fault line: Contributions to Mineralogy and Petrology, v. 92, p. 413-427, doi: 10.1007/ BF00374424.

Jäger, E., 1962, Rb-Sr age determinations on micas and total rocks from the Alps: Journal of Geophysical Research, v. 67, p. 5293-5306, doi: 10.1029/JZ067i013p05293.

Janots, E., Negro, F., Brunet, F., Goffé, B., Engi, M., and Bouybaouene, M.L., 2006, Evolution of the REE mineralogy in HP-LT metapelites of the Sebtide complex, Rif, Morocco: Monazite stability and geochronology: Lithos, v. 87, p. 214-234, doi: 10.1016/j.lithos.2005.06.008.

Janots, E., Brunet, F., Goffé, B., Poinssot, C., Burchard, M., and Cemic, L., 2007, Thermochemistry of monazite-(La) and dissakisite(La): Implications for monazite and allanite stability in metapelites: Contributions to Mineralogy and Petrology, v. 154, p. 1-14, doi: 10.1007/s00410-006-0176-2.
Janots, E., Engi, M., Berger, A., Allaz, J., Schwarz, J.-O., and Spandler, C., 2008, Prograde metamorphic sequence of REE minerals in pelitic rocks of the Central Alps: Implications for allanite-monazite-xenotime phase relations from 250 to $610^{\circ} \mathrm{C}$ : Journal of Metamorphic Geology, v. 26, p. 509-526, doi: 10.1111/ j.1525-1314.2008.00774.x.

Livi, K.J.T., Ferry, J.M., Veblen, D.R., Frey, M., and Connolly, J.A.D., 2002, Reactions and physical conditions during metamorphism of Liassic aluminous black shales and marls in central Switzerland: European Journal of Mineralogy, v. 14, p. 647-672, doi: 10.1127/ 0935-1221/2002/0014-0647.

Michalski, I., and Soom, M., 1990, The Alpine thermo-tectonic evolution of the Aar and Gotthard massifs, central Switzerland: Fission track ages on zircon and apatite and K-Ar mica ages: Schweizerische Mineralogische und Petrographische Mitteilungen, v. 70, p. 373-387.

Pfiffner, O.A., Ellis, S., and Beaumont, C., 2000, Collision tectonics in the Swiss Alps: Insight from geodynamic modeling: Tectonics, v. 19, p. 1065-1094, doi: 10.1029/2000TC900019.

Roselle, G.T., Thüring, M., and Engi, M., 2002, MELONPIT: A finite element code for simulating tectonic mass movement and heat flow within subduction zones: American Journal of Science, v. 302, p. 381-409, doi: 10.2475/ ajs.302.5.381.

Rubatto, D., and Hermann, J., 2001, Exhumation as fast as subduction?: Geology, v. 29, p. 3-6, doi: 10.1130/0091-7613(2001)029<0003:EAFAS> 2.0.CO;2.

Schlunegger, F., and Willett, S., 1999, Spatial and temporal variations in exhumation of the central Swiss Alps and implications for exhumation mechanisms, in Ring, U., et al., eds., Exhumation processes: Normal faulting, ductile flow and erosion: Geological Society of London Special Publication 154, p. 157-179, doi: 10.1144/GSL.SP.1999.154.01.07.

Schmid, S.M., Pfiffner, O.A., Froitzheim, N., Schönborn, G., and Kissling, E., 1996, Geophysical-geological transect and tectonic evolution of the Swiss-Italian Alps: Tectonics, v. 15, p. 1036-1064, doi: 10.1029/96TC00433

Steinmann, M., 1994, Ein Beckenmodell für das Norpenninikum der Ostschweiz: Jahrbuch der Geologischen Bundesanstalt, v. 137, p. 675-721.

Todd, C.S., and Engi, M., 1997, Metamorphic field gradients in the Central Alps: Journal of Metamorphic Geology, v. 15, p. 513-530, doi: 10.1111/j.1525-1314.1997.00038.x.

Vance, D., and O'Nions, R.K., 1992, Prograde and retrograde thermal histories from the Central Swiss Alps: Earth and Planetary Science Letters, v. 114, p. 113-129, doi: 10.1016/0012-821X(92)90155-O.

Vance, D., Müller, W., and Villa, I.M., 2003, An introduction, in Vance, D., et al., eds., Geochronology: Linking the isotopic record with petrology and textures: Geological Society of London Special Publication 220, p. 1-24.

Wing, B.A., Ferry, J.M., and Harrison, T.M., 2003, Prograde destruction and formation of monazite and allanite during contact and regional metamorphism of pelites: Petrology and geochronology: Contributions to Mineralogy and Petrology, v. 145, p. 228-250.

Manuscript received 26 May 2008

Revised manuscript received 3 September 2008 Manuscript accepted 4 September 2008

Printed in USA 